\title{
The Non-toxicity of Bacillus anthracis Gell Material
}

\author{
BY H. K. KING AND JEAN H. STELN \\ The Bacteriology Department, University of Edinburgh
}

SUMMARY: Suspensions of Bacillus anthracis, grown under various conditions, and disintegrated by shaking with minute glass particles, were not toxic to mice. The organisms were grown on both simple and complex media, aerobically and anaerobically, with and without extra carbon dioxide, for periods of from $6 \mathrm{hr}$. to 10 days.

The highly pathogenic Bacillus anthracis has always presented a puzzle to pathologists since no toxin has ever been demonstrated (for references, see Cromartie, Bloom \& Watson, 1947). Toxin production may require special conditions of culture not yet determined (cf. Gladstone, 1946, 1948); also, the preparation from a sporing organism of sterile extracts for animal experiments presents difficulties. The method of rapidly disintegrating bacteria by shaking with minute glass beads (Curran \& Evans, 1942; King \& Alexander, 1948) has now been used for attempting the demonstration of an endotoxin in $B$. anthracis, since spores are as readily destroyed as vegetative organisms. Though complete sterility is not always easily attained, the vast majority of cells in a suspension are killed by a few hours' shaking, while as far as is known labile cell constituents, e.g. enzymes, are not damaged (Gale, 1946).

\section{METHODS}

Organisms. Two strains of $B$. anthracis were used: strain ' $D$ ' from our laboratory stock, and N.C.T.C. no. 5180. The two organisms were passaged through mice three times and the approximate minimum lethal dose (M.L.D.) was then found to be 2000 organisms for each strain.

Media. The following media were used; the abbreviations are those used in Table 1: (a) nutrient agar (N.A.); (b) blood agar (B.A.), nutrient agar with the addition of $5 \%$ of sterile horse blood; (c) peptone water (P.W.), $1 \%$ peptone; (d) the horseflesh digest (H.F.D.) of Mackie \& McCartney (1948); (e) blood broth (B.B.), nutrient broth with addition of $5 \%$ sterile horse blood; $(f)$ serum broth (s.B.), nutrient broth with addition of $20 \%$ horse serum. The blood media were incubated before use to test their sterility.

Conditions of culture. 'Aerobic' signifies culture in a shallow layer of medium with free access of air; 'semi-aerobic', in a closed $500 \mathrm{ml}$. bottle half-filled with medium; 'anaerobic', growth in a McIntosh \& Fildes anaerobic jar. In some cases a gas-phase enriched with carbon dioxide was used. The incubation temperature was usually $37^{\circ}$ but sometimes $22^{\circ}$.

Technique. The medium was inoculated and incubated for the time and under the conditions shown in Table 1. The organisms were then harvested-by washing off with saline from solid media, or by centrifugation from liquid media. The harvested cells were washed twice on the centrifuge with saline. With blood broth, the washing was performed with distilled water to lyse the 
erythrocytes. The organisms were finally suspended in a suitable volume of saline and the approximate concentration of the suspensions determined by means of Brown's opacity tubes.

The organisms were disintegrated as follows. In most cases $40 \mathrm{ml}$. of suspension were transferred to a $4 \mathrm{oz}$. screw-cap flat medicine-type bottle containing $40 \mathrm{~g}$. of grade 12 'ballotini'; i.e. glass balls with an average diameter of $0.13 \mathrm{~mm}$. (Messrs Chance Bros., Smethwick, England). The bottle was placed lengthwise in the shaking machine and shaken horizontally at 500 strokes/min. with a $2 \frac{1}{2}$ in. stroke until sterility was achieved or, in a few cases, until the viable count had fallen to a sufficiently low value for the number of live organisms remaining in the material injected to be only a small fraction of the M.L.D. Smaller vessels were used for small volumes. The technique was essentially that of King \& Alexander (1948), but a higher rate of shaking permitted readier attainment of sterility. All vessels and reagents were sterile and aseptic precautions were observed throughout. A viable count was performed on the disintegrated material, which was regarded as sterile if no live organisms were found in $\mathbf{0 . 1} \mathrm{ml}$.

A suitable quantity of the disintegrated suspension was injected into mice, usually $0.5 \mathrm{ml}$. intraperitoneally, but sometimes $0.2 \mathrm{ml}$. subcutaneously or intravenously. The dose was usually adjusted to contain the equivalent of about $500 \times 10^{6}$ organisms. When very dense suspensions were shaken it was difficult to attain sterility or even a sufficient decrease in the viable count. In Exp. 30 where $70,000 \times 10^{6}$ organisms in $1 \mathrm{ml}$. saline were given, the disintegrate was centrifuged and the sterile supernatant used for the test. Usually three mice were used for each test, and the result was considered negative if the animals survived 7 days. Cultures were made from the spleen and heart blood of any animals dying within this period.

In all experiments with liquid media, the culture fluid was examined for exotoxins, though their presence was most unlikely. The supernatant was filtered through a ' $5 / 3$ ' sintered glass filter and the sterile filtrate tested for toxin by injecting $0.5 \mathrm{ml}$. intraperitoneally into each of three mice.

\section{RESULTS}

The results are set out in Table 1 . In no case were the disintegrated organisms or the culture filtrates lethal, with the exception of a few cases in which $B$. anthracis was recovered from the heart or spleen, or in which other pathogenic organisms, e.g. Salmonella, were found. Since these experiments yielded no evidence of toxin formation, we considered the possibility of toxin being produced in vivo. The spleens of anthrax-infected mice were selected as the source of material; these usually contain large numbers of the bacilli at death. The mice were infected and either allowed to die, or killed when moribund; this reduced the risk of a labile toxin being destroyed by the autolytic enzymes liberated at death. The spleens of two or three mice were removed and transferred aseptically to a sterile $25 \mathrm{ml}$. screw-capped bottle containing $5 \mathrm{ml}$. water and $5 \mathrm{~g}$. ballotini and sterilized by shaking for $10 \mathrm{hr}$. The resulting material was freeze-dried, each spleen yielding about $10 \mathrm{mg}$. dry material. There was 
Table 1. Preparations of disintegrated Bacillus anthracis which proved to be non-toxic when injected into mice

Strain of

Exp. no. organisms

\begin{tabular}{rcl}
\hline 1 & D & N.A. \\
$\mathbf{2}$ & $\mathbf{D}$ & B.A. \\
$\mathbf{3}$ & $\mathbf{D}$ & B.A. \\
$\mathbf{4}$ & $\mathbf{5 1 8 0}$ & B.A. \\
$\mathbf{5}$ & $\mathbf{5 1 8 0}$ & P.W. \\
$\mathbf{6}$ & $\mathbf{5 1 8 0}$ & P.W. \\
$\mathbf{7}$ & $\mathbf{5 1 8 0}$ & P.W. \\
$\mathbf{8}$ & $\mathbf{5 1 8 0}$ & P.W. \\
$\mathbf{9}$ & $\mathbf{5 1 8 0}$ & P.W. \\
$\mathbf{1 0}$ & $\mathbf{D}$ & B.B. \\
$\mathbf{1 1}$ & $\mathbf{D}$ & B.B. \\
$\mathbf{1 2}$ & $\mathbf{5 1 8 0}$ & B.B. \\
$\mathbf{1 3}$ & $\mathbf{5 1 8 0}$ & B.B. \\
$\mathbf{1 4}$ & $\mathbf{5 1 8 0}$ & B.B. \\
$\mathbf{1 5}$ & $\mathbf{5 1 8 0}$ & B.B. pH 8 \\
$\mathbf{1 6}$ & $\mathbf{5 1 8 0}$ & B.B. pH $\mathbf{6}$ \\
$\mathbf{1 7}$ & $\mathbf{5 1 8 0}$ & B.B. \\
$\mathbf{1 8}$ & $\mathbf{5 1 8 0}$ & B.B. \\
$\mathbf{1 9}$ & $\mathbf{5 1 8 0}$ & B.B. \\
$\mathbf{2 0}$ & $\mathbf{5 1 8 0}$ & S.B. \\
$\mathbf{2 1}$ & & \\
$\mathbf{2 2}$ & $\mathbf{5 1 8 0}$ & S.B. \\
$\mathbf{2 3}$ & $\mathbf{5 1 8 0}$ & S.B. \\
$\mathbf{2 4}$ & & \\
$\mathbf{2 5}$ & $\mathbf{5 1 8 0}$ & H.F.D. \\
$\mathbf{2 6}$ & & \\
$\mathbf{2 7}$ & $\mathbf{5 1 8 0}$ & B.B. \\
$\mathbf{2 8}$ & $\mathbf{D}$ & N.A. \\
$\mathbf{2 9}$ & & \\
$\mathbf{3 0}$ & $\mathbf{D}$ & B.A. \\
\hline $\mathbf{1 0}$ & &
\end{tabular}

\section{Temp. Duration}

incubation incubation

$\mathbf{8 7}{ }^{\circ}$

$\mathbf{3 7}^{\circ}$

$\mathbf{3 7}^{\circ}$

$\mathbf{2 2}^{\circ}$

$\mathbf{8 7}^{\circ}$

$22^{\circ}$

$22^{\circ}$

$37^{\circ}$

$\mathbf{3 7}^{\circ}$

$37^{\circ}$

$37^{\circ}$

$\mathbf{3 7}^{\circ}$

$\mathbf{3 7}^{\circ}$

$22^{\circ}$

$\mathbf{3 7}^{\circ}$

$\mathbf{3 7}^{\circ}$

$37^{\circ}$

$37^{\circ}$

$\mathbf{3 7}^{\circ}$

$\mathbf{3 7}^{\circ}$

$\mathbf{3 7}^{\circ}$

$\mathbf{3 7}^{\circ}$

$\mathbf{3 7}^{\circ}$

$37^{\circ}$

$37^{\circ}$
$24 \mathrm{hr}$.

$12 \mathrm{hr}$.

$24 \mathrm{hr}$.

$24 \mathrm{hr}$.

$24 \mathrm{hr}$.

3 days

3 days
$24 \mathrm{hr}$.

$24 \mathrm{hr}$.

$20 \mathrm{hr}$.

$20 \mathrm{hr}$.

$18 \mathrm{hr}$.

10 days

3 days

$24 \mathrm{hr}$.

$24 \mathrm{hr}$.

$6 \mathrm{hr}$.

$24 \mathrm{hr}$.

$24 \mathrm{hr}$.

$18 \mathrm{hr}$.

$18 \mathrm{hr}$.

$20 \mathrm{hr}$.

5 days

$16 \mathrm{hr}$.

$14 \mathrm{hr}$.

$20 \mathrm{hr}$.

Equivalent

total no.

of
organisms
injected $\begin{gathered}\text { Volume } \\ \text { injected }\end{gathered}$

(hr.) (millions) (ml.) Route

Aerobic

Aerobic

Aerobic, $30 \% \mathrm{CO}_{2}$

Aerobic

Aerobic

Aerobic

Aerobic, $30 \% \mathrm{CO}_{2}$

Anaerobic

Anaerobic, $10 \% \mathrm{CO}_{2}$

Aerobic

Anaerobic

Aerobic

Aerobic

Aerobic

Aerobic

Aerobic

Semi-aerobic

Semi-aerobic

Anaerobic, $10 \% \mathrm{CO}_{2}$

Aerobic

\section{Anaerobic}

Aerobic

Aerobic

Aerobic

Aerobic

\begin{tabular}{c}
24 \\
4 \\
24 \\
6 \\
41 \\
6 \\
3 \\
41 \\
1 \\
24 \\
24 \\
6 \\
18 \\
6 \\
4 \\
4 \\
6 \\
6 \\
6 \\
6 \\
\hline 5 \\
29 \\
6 \\
20 \\
12 \\
60
\end{tabular}

0.2 R.c.

$\begin{array}{rrr}20 & 0 \cdot 2 & \text { s.c. } \\ 150 & 0 \cdot 2 & \text { s c. }\end{array}$

$\begin{array}{lll}1500 & 0 \cdot 2 & \text { s.c. }\end{array}$

$\begin{array}{lll}300 & 0 \cdot 2 & \text { s.c. } \\ \mathbf{4 0 0} & \boldsymbol{\theta - 2} & \text { s.c. }\end{array}$

$\begin{array}{lll}400 & 0.2 & \text { s.c. } \\ 370 & 0.5 & \text { i.p. }\end{array}$

$900 \quad 0.5 \quad$ i.p.

370

370

200

300$$
\mathbf{3 7 0}
$$$$
600
$$$$
\begin{array}{r}
600 \\
500
\end{array}
$$$$
370
$$$$
\mathbf{3 7 0}
$$$$
\begin{aligned}
& \mathbf{3} 70 \\
& \mathbf{3 7 0}
\end{aligned}
$$$$
\begin{aligned}
& \mathbf{3 7 0} \\
& \mathbf{3 7 0}
\end{aligned}
$$$$
\begin{aligned}
& \mathbf{3 7 0} \\
& \mathbf{3 7 0}
\end{aligned}
$$$$
870
$$$$
\begin{aligned}
& 900 \\
& 500
\end{aligned}
$$$$
\begin{array}{r}
\mathbf{5 0 0} \\
\mathbf{3 7 0}
\end{array}
$$$$
\begin{array}{r}
370 \\
1,800
\end{array}
$$$$
\begin{array}{r}
1,800 \\
700
\end{array}
$$$$
0.5 \text { i.p. }
$$$$
0.5 \text { i.p. }
$$$$
0.5 \text { i.p. }
$$$$
\text { 0.2 s.c. }
$$$$
0.2 \text { s.c. }
$$$$
0.5 \text { i.p. }
$$$$
0.2 \text { i.p. }
$$$$
0.5 \text { i.p. }
$$$$
\text { 0.5 i.p. }
$$

$30,000 \quad 1 \cdot 0 \quad$ i.v.

Abbreviations. Media, see p. 48. Route of administration; s.c. subcutaneous; i.p. intraperitoneal; i.v. intravenous. 
no means of estimating the number of bacteria present or even the proportion of the dry weight which was bacterial material. No deaths occurred when mice were injected with the following doses: from spleens of mice which died, $0 \cdot 3 \mathrm{mg}$. in $0.2 \mathrm{ml}$. saline, intravenous, or $3.9 \mathrm{mg}$. in $0.5 \mathrm{ml}$. saline, intraperitoneal; from spleens of mice killed when moribund, $1.4 \mathrm{mg}$. in $0.2 \mathrm{ml}$. saline, intravenous, or $\mathbf{3 . 6} \mathrm{mg}$. in $0.5 \mathrm{ml}$. saline, intraperitoneal.

\section{DISCUSSION}

Violent shaking with minute glass beads, as used here, is believed to break open bacterial cells and to liberate the contents with relatively little damage to labile proteins. The period of shaking was considerably longer than is usually employed, for example, for the extraction of enzymes, where the aim is the disintegration of the majority of cells without necessarily sterilizing the culture. Even so we did not achieve sterility in every case, but always succeeded in so reducing the viable count that the volumes injected contained far less than the M.L.D. of the live organism. The prolonged shaking also involved risk of destruction of proteins by autolytic enzymes liberated from the cells. This point required special consideration in view of Gladstone's (1948) findings that the extracellular antigen of anthrax is readily destroyed by the organism's own proteolytic enzymes. Shaking was carried out at room temperature $\left(15^{\circ}\right.$ in most of our experiments) when enzyme action would be relatively slow. We consider that only a substance of quite exceptional lability would be destroyed under our conditions, and the validity of this method for treating endotoxins was demonstrated in a control experiment with Vibrio cholerae in which the M.L.D. of disintegrated organisms was shown to be the same as for those killed by mild heat.

Bearing in mind that a toxin might be produced only under certain special conditions, we used a wide range of cultural conditions, attempting in some cases to simulate the natural internal environment of the host. We used only moderate doses of the killed organisms to avoid confusing the issue with nonspecific protein toxicity. Dense suspensions proved difficult to sterilize; nevertheless, our mice resisted doses of $30,000 \times 10^{6}$ organisms. The cell material of the anthrax bacillus thus appears to possess a surprisingly low toxicity, and our results are in accord with the pessimistic view of Cromartie et al. (1947) that 'Our knowledge of anthrax in this respect (its pathogenic mode of action) has not been added to since the turn of the century'.

We wish to thank Prof. I. J. Mackie, C.B.E., for his interest in this work, which was performed during the tenure by one of us (H.K. K.) of the Lewis Cameron Teaching Fellowship of the University of Edinburgh.

\section{REFERENCES}

Cromartie, W. J., Bloom, W. L. \& Watson, D. W. (1947). Studies on infection with Bacillus anthracis, I. J. infect. Dis. 80, 1.

Curran, H. R. \& Evans, F. R. (1942). Killing of bacterial spores in fluids by agitation with small inert particles. J. Bact. 43, 125. 
Gar.r, E. F. (1946). The bacterial amino-acid decarboxylases. Advances Enzymol. 6, 1.

Gradstone, G. P. (1946). Immunity to anthrax: protective antigen present in cell-free filtrates. Brit. J. exp. Path. 27, 394.

GLadstone, G. P. (1948). Inmunity to anthrax: production of the cell-free protective antigen in cellophane sacs. Brit. J. exp. Path. 29, 379.

King, H. K. \& Alexander, H. (1948). The mechanical destruction of bacteria. J. gen. Microbiol. $2,315$.

MACKIE, T. J. \& MCCARTNEY, J. E. (1948). Handbook of practical bacteriology, 8th ed. p. 147. Edinburgh: E. and S. Livingstone.

(Received 30 April 1949) 